\title{
EXAMINING OF DETERMINANTS OF NON-PERFORMING LOANS
}

\section{Nikola Radivojevic, Jelena Jovovic*}

\begin{abstract}
In this paper the authors examine the determinants of NPL ratio using a cross-county analysis from the sample of 25 emerging countries. Using the panel data approach, determinants of NPL are analysed for the period from 2000 to 2011. The main aim of this paper is to draw a relevant econometric model, to demonstrate the impact of independent variables on the dependent variable by using static and dynamic model estimation techniques. The results show that NPLs rate can be mainly explained by crucial macroeconomic factors, such as the GDP and inflation rate, and bank-specific factors, such as ROA, CAP and lagged NPLs rate.
\end{abstract}

Keywords: non-performing loans, credit risk, macroeconomic factors, bank-specific factors, static and dynamic panel

JEL Classification: G24, C22, C52, C53

\section{Introduction}

It is common knowledge that financial institutions play a vital role in the economy by allocating capital from surplus agents to deficit agents in various economic sectors (Fukida, Dahalan, 2012). This means that a sound banking sector is necessary for economic growth because it ensures macroeconomic stability and develops sound financial institutions (Jovovic, 2014). However, during the last two decades, the deregulation process has strengthened competition among banks. Competition increased banks' credit risk, i.e. affecting their loan portfolios in terms of bad loan screening procedures and relaxing borrowing criteria (e.g. Manove et al. (2001), Bolt, Tieman (2004), Jeong, Jung (2013)). This has led to a significant increased level of non-performing loans (NPLS), which affects the liquidity and profitability of banks and thereby the financial stability of the banking systems and, in general, the macroeconomic stability.

Many indicators are used to measure banks' lending activity, but the most commonly used indicators to identify credit risk are non-performing loans to total loans (NPLs) and loan loss provision to total loans $(L L P)$.

Prior to the financial crisis in the last decade, the quality of the loan portfolio credit remained relatively stable. Thereafter, the quality of the banks' lending activity exacerbated sharply. The deterioration of the quality of banks' loan portfolios caused distress in the banking sector in both developed and emerging economies. The problem of the increase of NPL ratio is evident in the banking sector in many countries. Saba (2012) states that, since 2008 the level of NPLs has remarkably increased and the link between

* Nikola Radivojevic, High Technical School at Applied Studies, Kragujevac, Serbia (radivojevic034@gmail.com); Jelena Jovovic, Bona Fides, Kragujevac, Serbia (jelena.jovovic13@gmail.com). 
NPLs and decline of banks' credibility is considered as a main factor of the failure of credit policy. It is well-known that the stability of the financial sector and its likelihood of distress depend highly on the portion of the NPLs; thus NPLs serve as an indicator of defaults in the financial sector. A number of studies have shown that excessive credit growth often precedes financial crisis.

The aim of this paper is to carry out deep panel data analysis despite of detection of the relationship between macro and micro environment over NPLs. This paper contributes to the literature by investigating the determinants of the aggregate loan quality in 25 emerging countries using the former indicator of banks' credit quality - NPLS.

The paper has the following structure: The first section contains the introduction. Section 2 provides evidence on the relative studies and theoretical patterns based on the previous studies. Section 3 contains the description of econometric methodology used in the paper. In the Section 4 the final empirical research can be found with the presentation of the outcomes. The final section summarizes the conclusions.

\section{Literature Review}

There are many studies conducted on the problem of default rate of loans in the banking sector, most of them based on the relationship between bank-specific variables and macroeconomic factors. The earliest empirical study is conducted by Keeton and Morris (1987). They found that the risk that banks were taking was one of the reasons for loan losses and credit failures.

Lis et al. (2000) econometrically identified loan losses through various banking and macroeconomic factors using a panel data of Spanish commercial and savings banks for the period 1985-1997. They found that gross domestic product (GDP) growth rate has a negative effect on problem loans, that bank size is negatively related to problem loans, while loan growth, collateral loans, net interest margin and market power are positively related to that. Nkusu (2011) analysed the linkage between non-performing loans and macroeconomic performance of 26 advanced economies from 1998 to 2009. He used only macroeconomic variables in his study. His findings revealed that a poor macroeconomic performance (i.e. slower GDP growth, higher unemployment or decreasing asset prices) could be related to the increasing non-performing loans in advanced economies. The findings of the study of De Bock and Demyanets (2012) showed that GDP growth rate, exchange rates and loan growth are the main determinants of NPLs in the examined countries. In contrast to Nkusu they analysed the determinants of bank asset quality in 25 emerging countries during 1996-2010, by examining only aggregate macroeconomic and credit indicators. Makri and Papadatos (2012) econometrically identify the determinants of credit risk in Greek banking sector by using $L L P$ as a proxy of loan defaults, for the period from 2001 to 2012 . They found that $L L P$ is positively affected by unemployment rate and public debt, but negatively affected by capital adequacy ratio.

There are many studies that are based on panel cross-country analysis. The regression model of Mileris (2012) indicates that there is a strong relationship between changes in the macroeconomic environment and the performance of loans. He states that unemployment rate and interest rates have a strong influence on the quality of loans in the banks. Saba (2012) argues that there is significant dependency among NPL ratio and interest rates and between total loans and NPL rate. 
Moinescu (2012) studied determinants of NPLs in Central and Eastern European countries (CEE) during the period between 2003 and 2011. Econometric results of his research confirm that GDP growth is the prominent macroeconomic explanatory variable of NPLs developments among CEE economies. He found that real GDP growth and the change in output gap were almost equally important. His analysis reveals a strong determination influence with a short-term impact of the economic performance on the non-performing loans ratio dynamics across the CEE banking systems. Stylized representation of the change in the banking book quality as a function of the amplitude of business cycle suggests that the larger the difference between peak and depth of economic growth, the higher the NPL ratio jump during recession period (Moinescu, 2012, 56). Similar findings were reported by Mileris (2012).

Makri et al. (2014) identified the factors affecting the NPL rate in the Eurozone's banking sector for the period between 2000 and 2008. Their findings reveal strong correlations between NPLs and various macroeconomic (public debt, unemployment, annual percentage growth rate of $G D P$ ) and bank-specific factors (capital adequacy ratio, rate of nonperforming loans of the previous year and $R O E$ ). Precisely, they found statistically significant and negative correlation between NPLs and ROE. They also found statistically significant and positive relationship between: 1) the dependent variable NPLs and its lagged value; 2) NPLs and public debt; 3) NPLs and the unemployment rate.

A notable branch of literature is related to the appraising role of bank-specific factors based on balance sheets of banks. Tabak (2005) employs semi-annual data from the Balance Sheet and the Income Statements of Brazilian banks for the period from 2000 to 2005 and finds that the credit risk is the major source of operational banking risk. He concluded that a high level of NPLs indicates that banks have high credit risk and if not regularly managed may induce banking failures. The similar approach was done in Greece. Precisely, Louzis et al. (2012) used panel data methods to examine the determinants of non-performing loans in the Greek banking sector, separately for each loan category. According to Louzis et al. (2012) the determinants of NPLs should not be seen only among macroeconomic variables considering the fact that they are external to the banking sector. Thus, the characteristic features and the choice of policy of each bank are predicted to have an impact on NPLS rate. The results indicate that the Greek banking sector can be explained by GDP, unemployment, interest rate, public debt and bank-specific factors such as management quality and performance. The leverage has a statistically positive influence on business and mortgage $N P L s$. In addition, the ROE indicator is statistically significant for mortgage and consumer NPLs while insignificant for the business NPLs. The impact on loan categories is obvious with mortgages being the least reactive to changes in the macroeconomic environment.

Lu et al. (2005) explored the relationship between banks' lending behaviour and NPLs by using the financial data from annual financial reports of all publicly listed companies. The results of this study show that the Chinese banks have a structured lending bias towards state-owned enterprises (SOE), especially those with high default risk. The study observes that the high-risk SOE were able to borrow more than the low-risk SOEs and non-SOEs (Lu et al., 2005).

Using panel regression analysis, Pain (2003) investigates the factors that can help explain the increases in loan-losses in the UK for crucial banks. He points out that macroeconomic variables can indeed affect banks' NPLs, but he states that bank-specific factors are also important considering the fact that a great percentage of lending to riskier 
sector, such as commercial companies, has been usually linked to higher provisions (Pain, 2003).

Espinosa and Prasad (2010) concluded that the NPLs ratio aggravates as economic growth weakens and interest rates rise by using a dynamic panel data from 80 banks in the Gulf Cooperation Council (GCC). Their model suggests that bad macroeconomic conditions may indeed affect the future levels of NPLs ratios. Vector autoregressive (VAR) effects were also examined in order to look for the feedback that increasing NPLs might have on economic growth. Economic activity should be strongly, statistically and significantly affected by credit according to this panel VAR model. Finally, according to Figlewski et al. (2012) the following macro factors are believed to have a great impact on banks' creditworthiness: Factors related to general macroeconomic environment (unemployment rate, inflation, etc.); Factors related to the direction in which the economy is moving (real GDP growth, the change in consumer sentiment, etc.); Factors of financial market conditions (interest rates, stock market returns, etc.).

\section{Data and Methodology}

The paper examines 25 emerging countries (Albania, Algeria, Bulgaria, Bosnia and Hercegovina, Croatia, Chile, Cyprus, Ghana, Greece, Hungary, Island, Ireland, Kazakhstan, Mauritania, Moldova, Montenegro, Macedonia, Slovenia, Senegal, Serbia, Pakistan, Romania, Tunisia, Ukraine and Zambia) for the period from 2000 to 2011. The data were collected from Federal Reserve Saint Louis Bank's, World Bank's, Bank of International Settlements's official websites and Eurostat database. Panel data approach is used to examine the results. Panel data analysis deals with data in which behaviour of entities is observed over time. The main purpose of panel data analysis is to note whether there is any pattern in the data collected over time and different entities (cross-sectional between different countries).

Considering the structural breaks for some of the data, an unbalanced panel data set is used. The effect over the dependent variable in pre-financial crisis period and mostly during the financial crisis is examined within this time span. The period after the financial crisis from 2011 to 2014 is not considered due to unavailability of the data.

\subsection{Data description}

The dependent variable in the study is the non-performing loans (NPLs) ratio, which represents the sum of borrowed money upon which the debtor is not able to make his or her scheduled payments for at least 90 days. The gross domestic product $(G D P)$, the unemployment rate $(U N R)$, the inflation rate $(I N F)$, the nominal effective exchange rate $(N E E R)$, the house price index $(H P I)$ and the return on equity $(R O E)$, the return on assets $(R O A)$, the bank's capital to assets $(C A R)$ ratio, the loan loss provision $(L L P)$ and the net interest margin ratio $(N I M R)$ are used as explanatory variables. The determinants of $N P L$ based either on macroeconomic conditions or bank specific factors were the subject of many studies done by numerous researchers. According to Boudriga et al. (2009), in order to fairly reduce non-representativeness of the sample, an aggregate data for the whole banking sector of each country (in contrast to the analysis of individual data for each bank) should be more suitable to use. Researchers often use panel data across many countries, in order to explain effects of macroeconomic factors, whereas for bank specific factors there is 
a frequent handling of panel data analysis from the sample of the biggest banks in one region or one country (Jovovic, 2014). As a matter of fact, both types of variables in one model are used in the paper, along with aggregate bank-specific factors which are gathered for the whole financial sector of the chosen country.

Selection of the variables was guided by the following: 1) that variables should be the ones significant for NPLs, especially for emerging markets, due to their specific characteristics, level of development, situation on the financial market and the like ${ }^{1}$; 2) that there are available data on all the variables for all the selected countries; 3) that conflicting results on their impact on NPLs can be found in literature.

The empirical researches show that NPLs are closely related to the economic and business cycle, i.e. behind every financial crisis there are macroeconomic factors, such as downturns in aggregated economic activity. When growth slows or turns negative, borrowers reduce their cash inflows, which in turn makes it difficult for them to pay the interest and principal on bank loans. Under these circumstances borrowers will face liquidity shortages and the delays in the fulfillment of their financial obligations to banks will likely increase. We used the GDP to measure the aggregated economic activity, because the GDP is highly informative on other relevant macroeconomic variables. For the purpose of the paper, the GDP variable has been transformed into logarithmic function and represents the GDP growth over years. It is expected that the rise of the GDP will cause a decline in the NPLs ratio.

According to the related literature, $U N R$ is one of the most important indicators of the NPLs ratio. For this reason, this variable is included into the research. The variable $U N R$ represents the number of the unemployed workforce as a percentage of total labour force. It is expected that higher unemployment rate will lead to a rise in NPLs rate.

High inflation rate is one of the biggest issues of the central banks in many emerging countries; therefore, their goal is to stop severe inflation and to keep the increase in prices to a minimum level. The higher the inflation rate, the higher the NPLs rate. This is because wages are assumed to be sticky, so they adjust less quickly than the overall increase in the prices in the economy. Therefore, people are more confronted with difficulties in paying back loans while prices are higher. It is expected that higher inflation rate will provoke rise in the NPLs ratio. However, Rinaldi and Sanchis-Arellano (2006) find a positive relationship between the inflation rate and NPLs. Theoretically, inflation should reduce the real value of debt and hence make debt servicing easier (Skarica, 2013).

In addition to these variables, which are standard empirical determinants of NPLs, two more macroeconomic variables are included in the study due to their importance for the selected countries: NEER and HPI. The influence of the exchange rate depreciations on NPLs can be of dual nature. The growth in foreign currency has a negative impact on the possibility of private borrowers to pay loans, because it is known that in the selected emerging countries borrowers take (long-term) loans in foreign (convertible) currency, but get their salaries in local currency. On the other hand, literature emphasizes that depreciation of national currency can have a positive impact on the decrease of NPLs,

$1 \quad$ Share prices are the best example for this. Even though it represents standard empirical determinants of NPLs, and its influence on NPLs is not directly obvious, it is not included in the study because, for most of these countries, stock market business is on a very low level. A good example of this are the countries of the Western Balkans which have a small trading volume (low market capitalization rate) and the emergence of nonsynchronous trading, although they have a long tradition of stock market operations. 
through an increase in export volumes and thus an improvement of the financial position of the corporate sector. NEERs have been used for the purpose of studying the influence of depreciation on national currency. For the purpose of the paper the $N E E R s^{2}$ are calculated as geometric weighted averages of bilateral exchange rates taken from the Bank of International Settlements statistics.

Swings in property prices ${ }^{3}$ have been extremely large and frequent in selected emerging countries. The impact of real estate price changes on NPLs can also be twofold. On the one hand, the growth of real estate price can lead through decreased NPLs through collateral. Moreover, the pledging of collateral decreases borrower's moral hazard. On the other hand, pledging collateral could increase problem loans, because banks have fewer incentive to screen and monitor properly (they will take over the collateral) and the worthier the collateral, the higher the optimism of banks (Manove et al. (2001), Salas and Saurina (2002)). In order to capture these effects NPLs, the HPI (2000 is equal 100) is included in our research.

The main criterion for the selection of micro variables, in addition to their availability of data and their importance to the business of banks, was that conflicting results about the variables' impact on the rate of NPLs could be found in literature. Variables selected are ROA, ROE, CAR, LLP and NIMR.

According to Godlewski (2004), Garsiya and Fernandez (2007) and Stakic (2014), $R O A$ and $R O E$ are the most important indicators of efficiency, profitability, i.e. the quality of bank management. $R O A$ indicates the management's ability to use its assets effectively in order to generate higher profits. The $R O A$ ratio is displayed as a percentage which is calculated by dividing company's annual earnings with its annual assets. On the other side, the $R O E$ measures the amount of net income compared to shareholders equity. It indicates banks' profitability. It is expected that banks with high efficient $(R O A)$ and high rate of profitability $(R O E)$ have less pressure regarding profit making, hence also a lower dependency on venturing into the risk exposed placement. At the same time, low-cost efficient and less profitable banks are having a higher degree of problems with a high rate of NPLs. Studies conducted by Godlewski (2004) and Stakic (2014) confirm these expectations. Low-cost efficiency and low $R O E$ are positively associated with an increase in the NPLs rate failure. However, research conducted by Garsiya and Fernandez (2007) showed that high $R O A$ and $R O E$ are followed by a higher risk exposure. Also, Boudriga et al. (2009) identified positive correlation between the aforementioned variables and NPLs.

In addition to these two variables, $C A R$ was included in the research as a standard empirical determinant of NPLs. Capital to assets represents the ratio of bank's capital, reserves and total assets including all nonfinancial and financial assets. The $C A R$ is a good indicator of bank's solvency, and at same time it is highly correlated with leverage. In literature, there is no consensus about sign of relationship between the capital adequacy and NPLs ratio. It is expected that the higher CAR will cause NPLs rate to decease, but there are arguments in favour of the fact that banks with higher $C A R$ are venturing into higher risk- taking activities, thus creating higher risk for credit portfolio (Rime, 2001), and therefore high NPL rates.

2 A decrease in the NEER represents a depreciation of the domestic currency.

3 Property prices may influence both demand and the availability of bank credit via various wealth effects. This is mainly related to the role of asymmetric information in credit markets which gives rise to moral hazard or adverse selection problems (Gertler and Gilchrist, 1998). 
It is similar with LLP. Usually it stands in direct relationship with the level of NPLs. When predicting the high level of capital losses banks are allocating higher provisioning in order to reduce simultaneously the unpredictability of profitability and strengthen their medium-term liquidity (Stakic, 2014). However, managers are free to use provisioning in order to demonstrate financial strength of the bank, in view of the fact that readiness to allocate higher reserves may be linked with a robust belief in the bank's future performances.

The NIMR represents a good indicator of how optimal the investment decisions that a bank makes are. A negative value denotes that the bank did not make an optimal decision. However, the research conducted by Salas and Saurina (2002) shows that this variable does not affect NPLs rate. On the other hand, Espinoza and Prasad (2010) point out that there is a significant relationship between the NIMR and the NPLs. A decrease in the NIMR can bring about a change in the credit policy, making it riskier. The risk increase will create a loan portfolio with higher default probability in the future, which is why the variable has been lagged few periods. For this reason, one and two lags of this variable are used in the research. A negative sign is expected for this variable.

\subsection{Econometric methodology}

The linear model for panel data is used in the paper. Using panel data techniques enables the control of the bias generated by potential heterogeneity. A static estimation and a dynamic panel estimation are used in the paper. ${ }^{4}$ So, our first model is expressed as the following:

$$
\begin{aligned}
& N P L_{i, t}=\beta_{1}+\beta_{2} G D P_{i, t}+\beta_{3} U_{N R_{i, t}}+\beta_{4} I N F_{i, t}+\beta_{5} E_{N N R_{i, t}+\beta_{6} H I P_{i, t}+\beta_{7} R O A_{i, t}+} \\
& +\beta_{8} R O E_{i, t}+\beta_{9} C A R+\beta_{10} L L P_{i, t}+\beta_{11} N I M R_{i, t}+\beta_{12} N I M R_{i i^{\prime}-1}+\beta_{13} N I M R_{i i^{\prime}-2}+\varepsilon_{i^{\prime} t}
\end{aligned}
$$

where

$N P L \quad$ is the aggregate of non-performing loans to total gross loan,

$G D P$ is the gross domestic product,

UNR denotes the unemployment rate,

$I N F \quad$ is the inflation rate,

ENNR is the nominal effective exchange rate,

$H I P$ is the house price index,

$R O A$ represents the return on assets,

$R O E$ represents the return on equity,

$C A R$ expresses the capital to assets ratio,

LLP denotes loan loss provision,

NIMR is the net interest margin ratio,

subscript $t$ corresponds to the examined period,

subscript $i$ corresponds to the examined country.

$4 \quad$ According to Jovovic (2014), there is a belief that there might be a high presence in effects of lagged NPLs on NPLs ratio itself. This means that static panel data estimation is inconsistent, so the use dynamic panel data estimation is needed, such as difference Generalized Method of Moments (GMM) or two-stage-least-squares method (2SLS). In other words, when the lagged dependent variable is added in the model, OLS and EE become inconsistent and biased. 


$$
\begin{aligned}
& N P L_{i, t}=\beta_{1}+\beta_{2} N P L s_{i, t-1}+\beta_{3} G D P_{i, t}+\beta_{4} U N R_{i, t}+\beta_{5} I N F_{i, t}+\beta_{6} E_{N N R_{i, t}+\beta_{7} H I P_{i, t}+\beta_{8} R O A_{i, t}+} \\
& \quad+\beta_{9} R O E_{i, t}+\beta_{10} C A R+\beta_{11} L L P_{i, t}+\beta_{12} N I M R_{i, t}+\beta_{13} N I M R_{i, t-1}+\beta_{14} N I M R_{i, t-2}+\varepsilon_{i^{\prime} t}
\end{aligned}
$$

Precisely, in the paper we used three types of static panel estimation: 1) the Fix panel estimation (FE), which examines the relationship between independent and dependent variables within the countries. FE is recommended when there is a correlation between entity's error terms and the dependent variable. Since every country has its individual characteristics that may or may not affect the behaviour of the dependent variable, the use of fix panel estimation is necessary. According to Wooldridge (2014), we needed to use FE in order to remove the effects of those time-invariant characteristics; 2) the Random effect estimation (RE), the use of which is recommended when it is believed that differences among countries have some influence on the NPLs; 3) the pooled Ordinary Least Square (OLS) estimation. If we compare the three sets of estimation methods, according to Wooldridge (2002), we can reveal the nature of the bias. The bias is caused when the unobserved effects are entirely or partially left in the error term. Comparing these three sets of estimation methods makes it possible to reveal the nature of the bias caused by leaving the unobserved effects entirely or partially in the error term.

One lag of the dependent variable is used in the model in order to obtain deeper insight into the presence of the effects of lagged NPLs on NPLs ratio itself. In other words, we used the dynamic model estimation. The dynamic model is estimated with Generalized Method of Moments (GMM) as it was introduced by Arellano and Bond (1991). The choice of this estimation is in line with the empirical investigations of Louziset et al. (2010) and De Bock and Demyanets (2012). Their estimation started by transforming all variables by differencing and then by using difference GMM. The GMM estimation is based on the first difference transformation of Equation 2 in the following fashion:

$$
\begin{gathered}
\Delta N P L_{i, t}=\beta_{1}+\beta_{2} \Delta N P L s_{i, t-1}+\beta_{3} \Delta G D P_{i, t}+\beta_{4} \Delta U N R_{i, t}+\beta_{5} \Delta I N F_{i, t}+\beta_{6} \Delta E N N R_{i, t}+\beta_{7} \Delta H I P_{i, t}+ \\
+\beta_{8} \Delta R O A_{i, t}+\beta_{9} \Delta R O E_{i, t}+\beta_{10} \Delta C A R+\beta_{11} \Delta L L P_{i, t}+\beta_{12} \Delta N I M R_{i, t}+\beta_{13} \Delta N I M R_{i, t-1} \\
+\beta_{14} \Delta N I M R_{i, t-2}+\Delta \varepsilon_{i, t}
\end{gathered}
$$

where $\Delta$ is the first difference operator. In the Equation 3, the lagged dependent variable $\triangle N P L s_{i, t-1}$ is expected to be correlated with $\Delta \varepsilon_{i, t}$, imposing a bias in the estimation. Furthermore, this model might cause bias due to the endogeneity of the explanatory variables which gives a rise to the autocorrelation problems. Arellano and Bond (1991) state that the problem of autocorrelation between the lagged dependent variable and the error term might be solved by adding additional instruments in the dynamic panel data model. The point is in estimating the model from the Equation 3 above by finding valid instruments that are not correlated with the error term. The valid instrument is from the first-differenced equation, $N P L s_{i, t-2}$ since it is highly correlated with $N P L s_{i, t-1}-N P L s_{i, t-2}$, but not correlated with $\varepsilon_{i, t}-\varepsilon_{i, t-1}$. The basic idea of GMM estimation is to have valid instruments that can be tested with the Sargan test for overidentification. Furthermore, the 2SLS estimation method is also used to solve the problem of endogeneity of one or more explanatory variables. Basically, 2SLS instrumental variables method allows for correlation between the explanatory variables and the error term.

Considering the foregoing, we used three different ways to estimate dynamic panel equation in the paper as follows: 1) 2-stage-least-squares (2SLS) estimation, which 
assumes that lagged dependent variable needs to be instrumented with all lagged regressors in the model; 2) the dynamic FE estimation; 3) one-step difference GMM, which was already explained above.

\section{Empirical Analysis}

Table 1 gives a summary of the descriptive statistics of the data set. As can be seen from Table 1, NPLs ranges from $11.24 \%$ to $48.58 \%$ and $N P L_{i t-1}$ from $11.24 \%$ to $49.04 \%$. The average value of the NPLs is $15 \%$ approximately, which stresses the need for future prudence in conducting credit politics. The GDP shows positive and negative values, indicating that, over observed period some selected emerging countries marked negative growth. Additionally, for the same period $U N R$ is very high. It takes values from $14.59 \%$ to $27.01 \%$. The $I N F$ records ranging from $3.9 \%$ to $36.08 \%$. The NEER takes value from $89.2 \%$ to $132.15 \%$. Descriptive statistics of HIP refers to the swings in property prices being extremely large and frequent in selected countries. High standard deviation of macroeconomic variables can be interpreted, among other things, as a consequence of great oscillations in economic activities of the selected countries. The $R O A$ illustrates a relatively low disparity between counties. However, it has to be mentioned that the $R O E$ records a relatively high disparity between countries, with a minimum value of $-2.85 \%$. Despite different standards and prudential regulations, a high average value of the $C A R$ is encouraging and indicates resilience of the banking sector to extreme shocks and macroeconomic instability. Values of $L L P$ can be interpreted in a similar way. The negative values of the NIMR mean that some banks did not make optimal decisions.

Table 1 | Summary Descriptive Statistics of Data Set

\begin{tabular}{|c|c|c|c|c|c|}
\hline Variables & Observations & Mean & Std. Dev. & Minimum & Maximum \\
\hline$N P L_{s}$ & 294 & 14.806 & 3.320 & 11.240 & 48.578 \\
\hline$N P L_{s, t-1}$ & 293 & 15.974 & 3.001 & 11.240 & 49.044 \\
\hline GDP & 294 & 1.357 & 5.587 & -3.651 & 3.801 \\
\hline UNR & 294 & 19.897 & 10.012 & 14.589 & 27.010 \\
\hline INF & 294 & 7.084 & 6.256 & 3.905 & 36.083 \\
\hline NEER & 294 & 110.229 & 6.287 & 89.201 & 132.154 \\
\hline HIP & 290 & 170.080 & 65.057 & 80.067 & 389.500 \\
\hline$R O A$ & 294 & 1.202 & 0.682 & -1.010 & 3.052 \\
\hline ROE & 294 & 0.937 & 0.781 & -2.849 & 7.217 \\
\hline$C A R$ & 294 & 19.004 & 9.052 & 8.730 & 24.056 \\
\hline LLP & 294 & 23.010 & 2.247 & 18.800 & 25.020 \\
\hline NIMR & 293 & 4.658 & 2.897 & -0.420 & 13.965 \\
\hline$N I M R_{t-1}$ & 292 & 4.700 & 2.501 & -0.601 & 12.367 \\
\hline$N I M R_{t-2}$ & 291 & 4.801 & 2.622 & -0.487 & 13.020 \\
\hline
\end{tabular}

Source: Author's calculations 
When it comes to an analysis of time-series, the first thing that has to be checked is the panel stationary by using a unit root test for stationary. For this reason, the Fisher's augmented Dickey- Fuller (ADF) test is applied on every single variable. It is found that almost all the series have a problem of non-stationarity, with the exception of the $R O A$, the $R O E$ and $C A R$. So, the first difference technique which deals with the non-stationarity has to be employed. The estimated results are presented in Table A1 in Appendix. The correlation matrix Table A2 is presented in the Appendix. As it can be seen in Table A2, the $R O A$ and the $R O E$ are highly correlated with each other $(0.853)$, like the $N I M R_{t-1}$ and the $N I M R_{t-2}(0.870)$, and consequently the variables the $R O E$ and the $N I M R_{t-2}$, are excluded from the research.

\subsection{Empirical results}

The results of the three different methods of static panel data estimation are presented in Table 2, while the results of the three different methods of dynamic panel data estimation are given in Table $3 .^{5}$ The findings are robust across all considered models.

Table 2 | Results from the Panel Regression of All Countries; Time - Period 2000-2011 (unbalanced) Dependent Variable: NPLS

\begin{tabular}{|c|c|c|c|c|c|c|}
\hline \multirow[b]{2}{*}{ Regressors } & \multicolumn{2}{|c|}{$\begin{array}{l}\text { Pooled OLS } \\
\text { estimation }\end{array}$} & \multicolumn{2}{|c|}{ Fixed Effects } & \multicolumn{2}{|c|}{ Random Effects } \\
\hline & Coefficient & $p$-value & Coefficient & $p$-value & Coefficient & $p$-value \\
\hline Constant & -3.85 & $0.052^{*}$ & $-18.040^{*}$ & 0.060 & $-9.010^{*}$ & 0.088 \\
\hline$G D P$ & $-2.088^{* * *}$ & 0.009 & $-1.068^{* * *}$ & 0.003 & $-1.070 * * *$ & 0.005 \\
\hline UNR & $1.859 * * *$ & 0.006 & $2.487^{* *}$ & 0.041 & $2.901^{* *}$ & 0.016 \\
\hline INF & $0.0031^{* *}$ & 0.017 & $0.054^{* *}$ & 0.037 & $0.093^{* *}$ & 0.076 \\
\hline NEER & $-0.981^{* * *}$ & 0.000 & $-0.681^{* * *}$ & 0.002 & $-0.777^{* * *}$ & 0.001 \\
\hline$H I P$ & $-0.112^{* *}$ & 0.092 & $-0.083^{*}$ & 0.076 & $-0.106^{*}$ & 0.028 \\
\hline$R O A$ & $-0.690^{* * *}$ & 0.002 & $-0.374^{* * *}$ & 0.001 & $-0.590^{* *}$ & 0.031 \\
\hline$C A R$ & $0.831^{* *}$ & 0.015 & $0.260^{* *}$ & 0.027 & $0.633^{* *}$ & 0.040 \\
\hline LLP & $0.395^{* *}$ & 0.036 & $0.208^{* *}$ & 0.033 & $0.233^{* *}$ & 0.013 \\
\hline$N I M R_{t-1}$ & $0.006^{*}$ & 0.062 & $0.084^{*}$ & 0.098 & $0.090^{* *}$ & 0.044 \\
\hline$R$-squared & \multicolumn{2}{|c|}{$50.90 \%$} & \multicolumn{2}{|c|}{$72.59 \%$} & \multicolumn{2}{|c|}{$62.80 \%$} \\
\hline F-statistic & \multicolumn{2}{|c|}{0.000} & \multicolumn{2}{|c|}{0.000} & \multicolumn{2}{|c|}{0.000} \\
\hline
\end{tabular}

Note: ${ }^{* * *}, * *, *$ indicate significance on $1 \%, 5 \%$ and $10 \%$, respectively. Dummies for time effects are omitted. Source: Author's calculations

$5 \quad$ Notice: Coefficients for the $N I M R_{t}$ are not shown in tables because they were not statistically important. All the models were estimated once again without this variable. 
All of the models have satisfactory characteristics. R-squared takes value from $50.9 \%$ in case of the pooled OLS estimation model, to $88.9 \%$ in case of the dynamic FE estimation model. In case of the static model estimation, as it can be seen in Table 2, the highest value of the R-squared is achieved when using FE estimation with explaining $72.59 \%$ of the variation independent variable by the used variables. ${ }^{6}$ The results of one-step difference GMM are represented in the third part of the Table 3. Using differenced values of the variables as the instruments for first-difference equation, it is found that the Sargan test for over-identification does not reject the null which means that the instruments involved are valid. The tests for first-order and second-order serial correlation yield the expected diagnosis. So, the test for the first-order serial correlation rejects the null hypothesis of no first-order serial correlation, but does not reject the null hypothesis that there is no second-order serial correlation. This is what one expects in a first-differenced equation with the original untransformed disturbances assumed to be not serially correlated (Baltagi, 2008).

Table 3 | Results from the Panel Regression of All Countries; Time - Period 2000-2011 (unbalanced) Dependent Variable: NPLs (\%)

\begin{tabular}{|c|c|c|c|c|c|c|}
\hline & \multicolumn{2}{|c|}{ Dynamic Fixed Effects } & \multicolumn{2}{|c|}{ 2SLS regression } & \multicolumn{2}{|c|}{ One-Step difference GMM } \\
\hline Regressors & Coefficient & Prob. & Coefficient & Prob. & Coefficient & Prob. \\
\hline Constant & $-0.552^{* *}$ & 0.018 & $-0.474^{* *}$ & 0.028 & $-0.338^{*}$ & 0.066 \\
\hline$N P L_{t-1}$ & $0.247^{* * *}$ & 0.000 & $0.228^{* * *}$ & 0.005 & $0.231^{* * *}$ & 0.001 \\
\hline GDP & $-1.049^{* * *}$ & 0.005 & $-1.080^{* * *}$ & 0.007 & $-1.061^{* * *}$ & 0.001 \\
\hline UNR & $2.531^{* * *}$ & 0.003 & $3.089^{* * *}$ & 0.006 & $2.380^{* * *}$ & 0.009 \\
\hline INF & $0.020^{* *}$ & 0.017 & $0.027^{*}$ & 0.091 & $0.013^{* *}$ & 0.028 \\
\hline NEER & $-0.625^{* *}$ & 0.025 & $-0.814^{* *}$ & 0.030 & $-0.533^{*}$ & 0.073 \\
\hline HIP & $-0.332^{* *}$ & 0.039 & $-0.066^{*}$ & 0.071 & $0.400^{* *}$ & 0.047 \\
\hline ROA & $-0.488^{* *}$ & 0.027 & $-0.260^{* *}$ & 0.033 & $-0.020^{* * *}$ & 0.001 \\
\hline CAR & $1.001^{*}$ & 0.076 & $0.901^{*}$ & 0.055 & $0.099 * *$ & 0.039 \\
\hline LLP & $0.116^{* * *}$ & 0.004 & $0.077^{* *}$ & 0.031 & $0.050^{* *}$ & 0.011 \\
\hline$N I M R_{t-1}$ & $0.020^{*}$ & 0.062 & $0.019^{*}$ & 0.088 & $0.002^{*}$ & 0.089 \\
\hline \multirow{3}{*}{ R-squared } & \multirow{3}{*}{\multicolumn{2}{|c|}{88.9}} & \multirow{3}{*}{\multicolumn{2}{|c|}{78.51}} & $\operatorname{AR}(1)$ & 0.009 \\
\hline & & & & & $\operatorname{AR}(2)$ & 0.407 \\
\hline & & & & & Sargan test & 0.613 \\
\hline F-statistic & \multicolumn{2}{|c|}{0.000} & \multicolumn{2}{|c|}{0.000} & & \\
\hline
\end{tabular}

Note: ${ }^{* * *},{ }^{* *},{ }^{*}$ indicate significance on $1 \%, 5 \%$ and $10 \%$, respectively. Dummies for time effects are omitted. Source: Author's calculations

6 The p-value of the Hausman test is 0.000 (which is less than 0.05) it can be concluded, based on this test, that the FE estimation is appropriate for this model. 
As it can be seen in Tables 2 and 3, the results show that there are:

1) a negative and significant relationship between the GDP (current) and the NPLs rate, as predicted by theory. This finding indicates that macroeconomic fluctuations are quickly transmitted to the problem loans of banks in emerging countries. By including lagged $G D P$ in the model, it can be concluded whether the impact of the current $G D P$ on the NPLs is higher or lower compared to lagged GDP. This, however, is not the subject of the paper;

2) a positive and significant correlation between UNR and NPLs rate. This finding supports the view that revealing that unemployment reduces households' disposable income and weakens borrower's ability to pay their loan instalments. Similar results were presented by Nkusu (2011), Louzis et al. (2012), Makri (2014) and etc.;

3 ) a positive and significant relationship between INF rate and NPLs. This result indicates that in selected emerging countries, inflation has negative impact to banks' asset quality. This finding points to the conclusion that the effect of higher interest rates due to inflation and declining economic conditions which are usually associated with rising inflation, prevail over the positive impact that inflation might have on borrowers debt servicing capacities. This conclusion is in line with Mileris (2012) and Nkusu (2011), but not in line with Jovovic (2014). She found that an insignificant and a positive relationship exists between INF rate and NPLs rate;

4) a negative and significant relationship between the NEER rate and the NPLs rate. The selected countries are characterized by high level of foreign currency loans, and it is expected that the NPLs ratio reacts strongly to exchange rate volatility. This result suggests that a depreciation of the domestic currency would lead to an increase in the NPLs rate, to the decline of creditworthiness of private debtors and the fact that export-oriented companies do not use the positive effects of depreciation of the national currency on export, due to low competitiveness of their products. This result is in contrast with the analysis conducted by Beck et al. (2015);

5) a negative and significant relationship between HIP (current) and NPLs rate. This result suggests that the growth of the HIP has an impact on reducing the NPLs rate, i.e. that giving stocks reduces moral hazard of the borrower to get into riskier credit arrangements while the bank's lending terms and their sensitivity remain the same;

6) a negative and significant relationship between the ROA and the NPLs rate. This result points out that a deterioration of this ratio lead to an increase in NPLs confirming the risk-taking behaviour of banks. This negative relationship is also in line with the argument that bad management leads to riskier activities and weak performance;

7) a positive and significant correlation between CAR and NPLs rate. This finding speaks of the attitude of banks towards risk-taking activities in cases of favourable capital adequacy. Banks with high $C A R$ are involved in high risk activities creating risky loan portfolios, and therefore high $N P L$ rates. Encouraged by the possibility of achieving greater profits, banks, from these countries, are conscientiously venturing into risk activities, simultaneously with the capital adequacy which is substantially above the regulatory required minimum. This means that their credit activities were aimed also toward less solvency debtors;

8) a positive and significant correlation between LLP and NPLs rate. This means that banks were allocated high provision, because they expected that clients would not be 
able to properly service their loans. In other words, the high provision was not used for signalizing financial strength of banks;

9) a positive and significant correlation between $N I M R_{t-1}$ and $N P L s$ rate. This finding is in line with the previous results. The explanation may be that the creditworthiness of the debtors deteriorated during the observed period, but it was possible for the debtors to borrow only with higher lending rates, which contributed to the increase NIMR, and NPLS rate;

10) a positive and significant correlation between the $N P L s_{t-1}$ and $N P L S$ rate in all specifications. This result is corroborated by the literature, highlighting the dynamic persistence of NPLS during the observed period.

\section{Conclusion}

In this paper we examined the determinants of $N P L$ ratio using a cross-county analysis from the sample of 25 emerging countries. Using the panel data approach, determinants of $N P L$ are analysed for the period from 2000 to 2011 . The results of this research are mostly in line with results of research conducted by many other authors.

The findings of this research suggest that the GDP has a crucial deterministic role for the NPLs ratio unveiling that the state of the economy of (selected) emerging countries is clearly linked to bank asset quality. In other words, a drop in economic activity in these countries is the most important risk for bank asset quality. This finding is in line with Jovovic (2014), Makri (2014), Saba (2012), Nkusu (2011) and many others. Precisely, this finding is in contrast with the analysis conducted by Tabak (2001), who found significant but positive link between the GDP and NPLs in case of the Brazilian banking system. By including lagged $G D P$ in the model, it can be concluded whether the impact of the current GDP on the NPLs is higher or lower compared to lagged GDP. This, however, is not the subject of the paper. All the used methods estimated a significant and positive correlation between $U N R$ and NPLS rate. Both of these coefficients are highly significant and economically very large showing that recent economic movements in emerging countries have a strong negative impact on their financial stability. At the same time, depreciations of domestic currency leads to an increase of the NPLs. The reason for this should be looked for in the high degree of lending in foreign currencies to unhedged borrowers and the low competitiveness of export companies.

Beyond the macroeconomic variables, interesting results appear for the bank-specific factors. The findings suggest that the performance of the banks has a significant influence on the NPLs rate. A significant and negative relationship between the ROA and the NPLS rate is found in this paper. This result is in line with the expectations. This indicates that 'bad' management might cause weaker performance of banks by applying riskier activities. Other microeconomic variables have a significant and positive impact on the growth of NPLs, noting that for the current NIMR a significant relationship with NPLs was not found. This means that its impact on NPLs, through changes in the bank's business policy change, is felt with delay. The positive relationship indicates that banks are likely to use NPLs as a tool for creating riskier portfolios. This result was documented in earlier research.

By applying the dynamic estimation approach, the results show that there is a highly significant and positive effect of lagged NPLs ratio. This finding highlights the dynamic persistence of $N P L s$ during the observed period. 


\section{Appendix}

Table A1 | Panel Unit Root Test

\begin{tabular}{|c|c|c|c|}
\hline & & statistics & $p$-value \\
\hline \multirow{2}{*}{$N P L_{s}$} & level & 30.2122 & 0.9879 \\
\hline & 1st Difference & 95.3647 & 0.0001 \\
\hline \multirow{2}{*}{$N P L_{s \cdot t-1}$} & level & 36.8410 & 0.9169 \\
\hline & 1st Difference & 98.2000 & 0.0007 \\
\hline \multirow{2}{*}{ LNGDP } & level & 45.3300 & 0.6609 \\
\hline & 1st Difference & 90.3648 & 0.0004 \\
\hline \multirow{2}{*}{ UNR } & level & 29.0001 & 0.9924 \\
\hline & 1st Difference & 103.3289 & 0.0000 \\
\hline \multirow{2}{*}{ INF } & level & 41.3970 & 0.8017 \\
\hline & 1st Difference & 201.0000 & 0.0000 \\
\hline \multirow{2}{*}{ NEER } & level & 39.2640 & 0.8630 \\
\hline & 1st Difference & 101.2000 & 0.0000 \\
\hline \multirow{2}{*}{ HIP } & level & 44.2558 & 0.7022 \\
\hline & 1st Difference & 137.2286 & 0.0000 \\
\hline$R O A$ & level & 73.2439 & 0.0177 \\
\hline ROE & level & 251.0214 & 0.0000 \\
\hline$C A P$ & level & 101.6400 & 0.0000 \\
\hline \multirow{2}{*}{ LIP } & level & 36.4831 & 0.9235 \\
\hline & 1st Difference & 203.0158 & 0.0000 \\
\hline \multirow{2}{*}{ NIMR } & level & 27.3691 & 0.9962 \\
\hline & 1st Difference & 117.3650 & 0.0000 \\
\hline \multirow{2}{*}{$N I M R_{t-1}$} & level & 32.0002 & 0.9777 \\
\hline & 1st Difference & 98.3645 & 0.0001 \\
\hline \multirow{2}{*}{$N I M R_{t-1}$} & level & 29.6651 & 0.9902 \\
\hline & 1st Difference & 203.3348 & 0.0000 \\
\hline
\end{tabular}

Panel Means: Included

Time trend: Not Included

Drift terms: Not Included

Source: Author's calculations 
Table A2 | The Correlation Matrix

\begin{tabular}{|c|c|c|c|c|c|c|c|c|c|c|c|c|c|c|}
\hline & $N P L_{s}$ & $N P L_{\text {s.t-1 }}$ & LNGDP & UNR & INF & NEER & HIP & $R O A$ & ROE & CAP & LLP & NIMR & $N I M R_{t-1}$ & $N I M R_{t-2}$ \\
\hline$N P L_{s}$ & 1.0000 & & & & & & & & & & & & & \\
\hline$N P L_{\text {s.t-1 }}$ & 0.5141 & 1.0000 & & & & & & & & & & & & \\
\hline LNGDP & 0.2472 & 0.2091 & 1.0000 & & & & & & & & & & & \\
\hline UNR & 0.1520 & 0.1318 & 0.4890 & 1.0000 & & & & & & & & & & \\
\hline INF & -0.1010 & -0.0891 & -0.0734 & 0.1961 & 1.0000 & & & & & & & & & \\
\hline NEER & 0.0428 & 0.0390 & -0.0462 & $\mid-0.0490$ & 0.5082 & 1.0000 & & & & & & & & \\
\hline HIP & -0.0711 & -0.0412 & 0.0211 & -0.0028 & 0.6015 & 0.0301 & 1.0000 & & & & & & & \\
\hline$R O A$ & $\mid-0.3642$ & -0.3017 & -0.0860 & -0.0526 & 0.1244 & 0.0280 & 0.0489 & 1.0000 & & & & & & \\
\hline ROE & -0.3011 & -0.2991 & -0.1981 & -0.0691 & 0.1026 & 0.0311 & 0.0391 & 0.8530 & 1.0000 & & & & & \\
\hline CAP & $\mid-0.0781$ & -0.0515 & -0.1237 & $\mid-0.0146$ & 0.0955 & 0.0220 & 0.0411 & 0.4861 & -0.2841 & 1.0000 & & & & \\
\hline LLP & 0.3017 & 0.2871 & 0.0726 & 0.2084 & -0.0357 & 0.0486 & -0.0267 & 0.3813 & -0.4019 & 0.4220 & 1.0000 & & & \\
\hline NIMR & -0.2519 & -0.2544 & 0.1011 & $\mid-0.0096$ & 0.0781 & -0.0265 & 0.0174 & -0.1380 & -0.1018 & -0.1230 & -0.0356 & -1.0000 & & \\
\hline$N I M R_{t-1}$ & -0.2035 & -0.2116 & 0.1132 & -0.0111 & 0.0811 & -0.0221 & 0.0193 & -0.1355 & 0.0981 & 0.1201 & -0.0281 & 0.5042 & 1.0000 & \\
\hline$N I M R_{t-2}$ & -0.1880 & -0.1901 & 0.1974 & -0.0160 & 0.0990 & -0.0149 & 0.0118 & -0.1420 & 0.1082 & 0.1160 & -0.0266 & 0.5830 & 0.8700 & 1.0000 \\
\hline
\end{tabular}

Source: Author's calculations

\section{References}

Arellano, M., Bond, S. (1991). Some Tests of Specification for Panel Data: Monte Carlo Evidence and an Application to Employment Equations. The Review of Economic Studies, 58(2), 277-297, http://dx.doi.org/10.2307/2297968

Baltagi, B., H. (2008). Econometric Analysis of Panel Data. 4th Ed. Chichester: Wiley.

Beck R., Jakubik, P., Piloiu, A. (2015). Key Determinants of Non-Performing Loans: New Evidence from a Global Sample. Open Economies Review, 26(3), 525-550, http://dx.doi.org/10.1007/ s11079-015-9358-8

Boudriga, A., Taktak, N., Jellouli, S. (2009). Bank Specific, Business and Institutional Environment Determinants of Nonperforming Loans: Evidence from MENA Countries. Paper presented at Economic Research Forum $16^{\text {th }}$ Annual Conference Cairo.

Bolt, W., Tieman, A. F. (2004). Banking Competition, Risk and Regulation. International Monetary Fund Working Paper WP/04/11.

De Bock, R., Demyanets, A. (2012). Bank Asset Quality in Emerging Markets: Determinants and Spillovers. International Monetary Fund Working Paper WP/12/71.

Espinoza, R., Prasad, A. (2010). Nonperforming Loans in the GCC Banking System and their Macroeconomic Effects. IMF Working Paper 224.

Godlewski, J. C. (2005). Bank Capital and Credit Risk Taking in Emerging Market Economies. Journal of Banking Regulation, 6(2), 128-145, http://dx.doi.org/10.1057/palgrave. jbr.2340187

Garsiya, M. T., Fernandez, R. M. D. (2008). Risk-Taking Behaviour and Ownership in the Banking Industry: The Spanish Evidence. Journal of Economics and Business, 60(4), 332-354, http:// dx.doi.org/10.1016/j.jeconbus.2007.04.008 
Figlewski, S., Frydman, H., Liang, W. (2012). Modelling the Effect of Macroeconomic Factors on Corporate Default and Credit Rating Transitions. International Review of Economics and Finance, 21(1), 87-105, http://dx.doi.org/10.1016/j.iref.2011.05.004

Fernandez de Lis, S., Martinez Pagés, J., Saurina, J. (2000). Credit Growth, Problem Loans and Credit Risk Provisioning in Spain. Banco de Espana, Working Paper 18.

Fukuda, T., Dahalan, J. (2012). Finance - Growth-Crisis Nexus in Asian Emerging Economies: Evidence from VECM and ADRDL Assessment. International Journal of Economic Sciences and Applied Research, 5(2), 69-100. Available at: http://ijbesar.teiemt.gr/docs/volume5_ issue2/finance_growth_crisis.pdf

Jeong, S., Jung, H. (2013). Bank Wholesale Funding and Credit Procyclicality: Evidence from Korea. Panoeconomicus, 60(5), 615-631, http://dx.doi.org/10.2298/pan1305615j

Jovovic, J. (2014). Determinants of Non-Performing Loans: Econometric Evidence Based on 25 Countries. Master Thesis, City University London.

Keeton, W., Morison, C., S. (1987). Why Do Banks' Loan Losses Differ? Federal Reserve Bank of Kansas City Economic Review, 72(5), 3-21.

Lis, F. S., Pagés, M., Saurina, J. (2000). Credit Growth, Problem Loans and Credit Risk Provisioning in Spain. Banco de Espana Working Paper 18.

Louzis, P. D., Vouldis, A. T., Metaxas, V. L. (2012). Macroeconomic and Bank-Specific Determinants of Non-Performing Loans in Greece: A Comparative Study of Mortgage, Business and Consumer Loan Portfolios. Journal of Banking and Finance, 36(4), 1012-1027, http://dx.doi.org/10.1016/j.jbankfin.2011.10.012

Lu, D., Thangavelu, S. M., Hu, Q. (2005). Biased Lending and Non-Performing Loans in China's Banking Sector. The Journal of Development Studies, 41(6), 1071-1091, http://dx.doi. org/10.1080/00220380500155361

Makri, V., Tsagkanos, A., Bellas, A. (2014). Determinants of Non-Performing Loans: The Case of Eurozone. Panoeconomicus, 61(2), 193-206, http://dx.doi.org/10.2298/pan1402193m

Makri, V., Papadatos, K. (2014). How Accounting Information and Macroeconomic Environment Determine Credit Risk, Evidence from Greece. International Journal of Economic Sciences and Applied Research, 7(1), 129-143. Available at: http://papers.ssrn.com/sol3/papers. cfm?abstract_id=2445745

Manove, M., Padilla, J., A., Pagano, M. (2001). Collateral versus Project Screening: A Model of Lazy Banks. RAND Journal of Economics, 32(4), 726-744, http://dx.doi. org/10.2307/2696390

Mileris, R. (2012). Macroeconomic Determinants of Loan Portfolio Credit Risk in Banks. Izerine Ekonomika-Engineering Economics, 23(5), 496-504, http://dx.doi.org/10.5755/j01. ee.23.5.1890

Moinescu, G. B. (2012). Determinants of Nonperforming Loans in Central and Eastern European Countries: Macroeconomic Indicators and Credit Discipline. Review of Economic and Business Studies, 5(2), 47-58.

Nkusu, M. (2011). Nonperforming Loans and Macrofinancial Ulnerabilities in Advanced Economies. IMF Working Paper 161.

Pain, D. (2003). The Provisioning Experience if the Major UK Banks: A Small Panel Investigation. Bank of England. Work Paper No. 177.

Rime, B. (2001). Capital Requirements and Bank Behaviour: Empirical Evidence for Switzerland. Journal of Banking and Finance, 25(4), 789-805, http://dx.doi.org/10.1016/ s0378-4266(00)00105-9 
Rinaldi, L., Sanchis-Arellano, A. (2006). Household Debt Sustainability: What Explains Household Non-Performing Loans? An Empirical Analysis. ECB Working Paper.

Saba, I. (2012). Determinants of Non Performing Loans: Case of US Banking Sector. Economic, 44(3), 81-121.

Salas, V., Saurina J. (2002). Credit Risk in Two Institutional Regimes: Spanish Commercial and Savings Banks. Journal of Financial Services Research, 22(3), 203-224, http://dx.doi. org/10.1023/a:1019781109676

Skarica, B. (2013). Determinants of Non-Performing Loans in Central and Eastern European Countries. Working Paper.

Stakic, N., (2014). Determinante kretanja nivoa porblematičnih kredita u bankarskom sektoru u Srbiji. (Determinants of the Nonperforming Loans Level Movement in the Banking Sector of Serbia) Bankarstvo, 43(4), 122-145, http://dx.doi.org/10.5937/ bankarstvo1404122s

Tabak, B. et al. (2005). The Stability-Concentration Relationship in the Brazilian Banking System. The Banco Central do Brazil Working Papers No. 145.

Wooldridge, J., M. (2009). Introductory Econometrics: A Modern Approach. 4th ed. Mason, Ohio: South-Western Cengage Learning. 